\title{
ПОСТСЕКУЛЯРНІ ВИМІРИ ОСВІТНІХ ТРАНСФОРМАЦІЙ
}

\author{
Цибулько О. С. \\ доктор педагогічних наук, професор, Маріупольський державний \\ університет, м. Маріуполь, Україна
}

Сучасний світ стає одночасно і більш «релігійним», більш «секулярним» в міру глобалізащії західно-християнської бінарної системи класифікації релігійно-секулярної реальності. Проблема освітніх трансформацій у постсекулярному світі в науковому пізнанні не завершена, але є передумови для подальшої рефлексї̈ для ії вирішення: різноманіття досвіду міркувань сприяє тому, що ия проблема перетворюється в випробувальний полігон методологій і експериментів.

Ключові слова: секуляризація, постсекулярний сочіум, релігійносекулярна свідомість, освіта.

Abstract. The modern world becomes more «religious», more «secular» at the same time, as the Western Christian binary system of classification of religious-secular reality globalizes. The problem of educational transformations in the post-secular world in scientific cognition is not complete, but there are prerequisites for further reflection to solve it: the diversity of experience of reasoning contributes to the fact that this problem becomes a testing ground for methodologies and experiments.

Key words: secularization, post-secular society, religious-secular consciousness, education.

У розгляді явища секуляризації можна відзначити, що більшість незахідних товариств стають все більш секулярними: космічний порядок все більше визначається сучасною наукою і технологіями, соціальний порядок все більше визначається взаємозв'язком «демократичних» держав, заснованих на принципі громадянства, а ринкова економіка і медійні громадські сфери все частіше апелюють до людської гідності, свободи, рівності і прагнення до щастя. Отже, в цілому, світ стає одночасно і більш «релігійним», більш «секулярним» в міру глобалізації західно-християнської бінарної системи класифікації релігійно-секулярної реальності.

Процес секуляризації в багатьох європейських суспільствах досяг точки неповернення. Релігія як «ланцюг пам’яті» втрачена без можливості відновлення, і цілі покоління молодих європейців ростуть, не 
маючи ніякого особистого ставлення до християнської релігійної традиції або навіть не знаючи про неї [3]. Не тільки християнські церкви, а й цілі сім’ї втратили свою роль в процесі релігійної соціалізації. Якщо не станеться якогось непередбаченого релігійного відродження, процес європейської секуляризації неможливо повернути назад.

При цьому, ні наївна секулярність, ні секуляристське саморозуміння не можуть вважатися здоровими, тобто їх не можна більше приймати як щось само собою зрозуміле, не ставлячи під сумнів або не піддаючи серйозній рефлексії.

Сам факт, що ми задаємося питанням про те, вступаємо ми в епоху всесвітнього постсекулярного суспільства, свідчить про те, що ми переступили поріг, що ми більше не можемо просто, без будь-якої рефлексії залишатися секуляристами [2].

Ю. Хабермас вважає, що вираз «постсекулярний» не просто віддає релігійним спільнотам данину суспільного визнання за функціональний внесок, який вони вносять в справу відтворення бажаних мотивів і установок. У суспільній свідомості постсекулярного соціуму відбивається ще й нормативне розуміння, що має значення для політичної взаємодії невіруючих громадян з віруючими. У постсекулярному соціумі складається визнання тієї обставини, що модернізація суспільної свідомості охоплює при переході до нової фази як релігійний, так і світський менталітет і рефлексивно видозмінює їх [1].

Отже, сучасний світ постає у межах бінарної реальності, оскільки релігійно-секулярна свідомость не розриває світ навпіл, а взаємодіє та розвивається у означеному напрямку. Проблема ж індивідуальної свідомості у постсекулярному світі в науковому пізнанні не завершена, але є передумови для подальшої рефлексії для іiї вирішення: різноманіття досвіду міркувань про «майбутнє релігії» сприяло тому, що ця проблема перетворилася в випробувальний полігон методологій і експериментів. Щоб в певній мірі поставити цю проблему як «публічну», вона повинна знову стати проблемою методологічно вивіреної філософської рефлексії в рамках «філософії майбутнього».

\section{Список використаних джерел:}

1. «A Postsecular World Society?»: An interview with Jürgen Habermas by Eduardo Mendieta, The Immanent Frame, 3.02.2010 URL: https://tif. ssrc.0rg/2010/02/03/a-p0stsecular-world-society/. 
2. Antonenko, T., Kachmar, O., Tsybulko, O., Grachova, T., \& Konovalova, M. (2020). Scientific Approaches to Postmodern Spirituality: Theoretical and Methodological Aspects. Postmodern Openings, № 11 (2). Supl. 1, P. 200-214. URL:https://doi.org/10.18662/po/11.2Sup1/187

3. Mozghovyi, L., Muliar, V., Stepanova, O., Ignatyev, V., \& Stepanov, V. (2021). Religious-Secular Reality of Individual Consciousness In The Context of COVID-19. Postmodern Openings, № 12 (2), P. 522-534. URL:https://doi. org/10.18662/po/12.2/322 